Seminars, Conferences, Addresses

\title{
The Middle East Studies Association of North America
}

San Antonio, Texas

Rabi' al Akhir 21-2A, JAH/November 10-13, 1990

The twenty-fourth annual meeting of the Middle East Studies Association of North America (MESA) was held between November 10-13, 1990 in San Antonio, Texas. Hosted by the Center for Middle Eastern Studies of the 
University of Texas at Austin and supported by different academic organizations, MESA featured a number of distinguished speakers, international and domestic, who spoke on a wide variety of topics.

One topic was the Gulf crisis and the Arab/Israeli conflict. The plenary session of MESA, entitled "The Current Crisis in the Gulf: Thoughts and Reflections," featured three main speakers: Richard Murphy of the Council on Foreign Relations, Rashid Khalidi of the University of Chicago, and Kenneth Stein of Emory University. Though this session did not discuss ways of solving the Gulf crisis, it was the general feeling of the audience that a linkage does exist between the Gulf situation and the Arab/Israeli conflict, and that a comprehensive solution in which the U.S. should play a major part is urgently needed.

The conference tackled another current complication in the Middle East during its seminar entitled "The Impact of the Possible Mass Immigration of Soviet Jews to Israel and the Occupied Territories." Walid Khalidi of Harvard University expressed the feeling of perhaps millions of Palestinians when he said that this mass immigration of Soviet Jews is the second most dangerous situation affecting the Palestinians after their expulsion from their land in 1948. Israel has by now received 200,000 Soviet immigrants since the summer of 1990, and their number is expected to reach two million by the year 1995 . Muhammad Hallaj of the Palestine Research and Educational Center, located in Fairfax, Virginia, discussed the impact of the Soviet Jews' mass immigration on Palestinian demography and economy in the occupied territories, and showed how Israeli politicians, especially the right-wing ones, are more agreeable than before to transferring a large number of Palestinians to Arab countries, especially to Jordan. As is well known, since 1967 a number of influential Israeli politicians have called on successive Israeli governments to expel Palestinians en masse as a means of keeping the demographic balance in favor of the Jewish population. It should be noted, however, that transfer, albeit on a minor scale, has in effect taken place, especially since the start of the Palestinian intifada in December of 1987. More than 200 Palestinian leaders, many of whom belong to the Islamic movement HAMAS, have been deported to Lebanon. This shows the resolve of the Israeli government in getting rid of the vital elements of Palestinian society.

The MESA conference also featured a number of talks on Islamic history, the political economy of the Muslim world, the current situation of Islamic activism and resurgence, and the Islamization of knowledge. Mahmood Ibrahim of California State Polytechnic University spoke on iqtā 'and the periodization of Islamic history, and Peter von Sivers of the University of Utah discussed the organization of agricultural labor in medieval Islamic society. All of these talks were intended to show the economic infrastructure of the Islamic state in the medieval period and how the economy contributed to intellectual and 
religious revitalization in Islamic lands. A session chaired by John O. Voll of the University of New Hampshire emphasized yet another important dimension of Islamic intellectual and religious activity: revivalism and Sufi orders in eighteenth- and nineteenth-century Islam. Sajida S. Alvi of McGill University talked about Mazhar Jān-i-Jānān, a Naqshbandī shaykh of eighteenth-century India, Nehemia Levtzion and Gideon Wieert of the Hebrew University in Jersualem spoke on the Khalwatiyah revial in Ottoman Egypt in the eighteenth century, and Knut Vikor spoke on the al Sanūsī and Hasan al 'Atțār's fatwas on jihad.

In addition, a whole session was devoted to issues and directions in premodern Islamic historiography, and was chaired by Christopher Taylor of Yale University. Taylor himself spoke on the pilgrimage guides to the cemeteries of medieval Cairo as a new source for the social history of religion, Joseph Roberts spoke on the Ghulāt in medieval Islamic historiography, and finally Jonathan Berkey of Mount Holyoke College spoke on waqfiyahs as a source for the history of religious institutions in Mamlūk Cairo.

Islamization and Islam and politics were the key topics in an important panel chaired by Manocherhr Dorraj of Texas A\&M University. James Coyle of George Washington University tackled the possible connection between classical and medieval Islamic political theory and the modern one, especially as manifested in the thought of the Egyptian Muslim activist al Faraj. He argued that a strong connection exists between modern Islamic activism and traditional Islamic theology and philosophy. It should be noted, however, that this thesis is borrowed entirely from Emmanuel Sivan's work on Radical Islam: Medieval Theology and Modern Politics (New Haven and London: Yale University Press, 1986 and 1990).

Bassam Tibi of the University of Gottingen presented a secular sociological critique of the Islamization of knowledge, especially the one pioneered by the International Institute of Islamic Thought. From the outset, Tibi declared that he was against any attempt at Islamization and stressed the need for a pragmatic sociological discussion of issues involving Islam and other aspects of society. Furthermore, Tibi criticized a number of contemporary Muslim thinkers, especially Muhammad 'Ammārah of Cairo, for elevating revelation over human reason. In return, Tibi was criticized by a number of people in the audience who argued on behalf of Islamization and the supremacy of metaphysics, theology, and tradition in Islam.

Raymond Hinnebusch of the College of St. Catherine spoke on the roots of Islamic resurgence in Syria from a comparative perspective. He skillfully presented the activities of the Muslim Brotherhood over the past few decades in Syria and how this group evolved in interaction with or opposition to Ba'athism as the ideology of Syrian Arab nationalism, and stressed the need to analyze this evolution on the basis of three factors or levels: 1) the ideology 
of the Muslim Brotherhood; 2) the political context; and 3) the social composition of Muslim Syrian society. Hinnebusch showed how the state encouraged Westernization and secularization at the expense of entrenched Islamic values, and how power became concentrated in a few hands. On the ideological level, the Syrian Ikhwän were able to present a viable ideological alternative to Arab Baathist nationalism by emphasizing the religious integrity of the ummah and by opposing any capitalist penetration of Syrian society. Politically speaking, the Sunni majority became disenchanted with the rule of the Alawi minority, especially because the political leadership of the country came from a tiny sect. As for the social composition, Hinnebusch said that though the Muslim Brotherhood failed to reach all strata of society, it was nevertheless successful in attracting a large number of lower- and middleclass citizens who saw the need for the reestablishment of the Islamic state and Islamic values. Hinnebusch then took the specific example of the Muslim Brothers' activist Marwān Hadīd who was killed by the Syrian army in 1974.

Next, David Commins of Dickinson College addressed Islamic activism on the West Bank during Jordanian rule. He discussed the liberation party (Hizb al Tahrīr) and its founder Shaykh Taqī al Dīn al Nabahānī. He talked about the evolution of the party in the fifties and the sixties, as well as its present situation in Jordan. The last talk was given by Chad Emmet of Brigham Young University in Utah on Islamic activism in the city of Nazareth. Being the major Palestinian city in Israel and controlled for many years now by the Israeli Communist Party, Emmet noted that there has been a sharp decline in the support given to the Communist Party, especially in Muslim neighborhoods, a development that coincided with the rise of Islam as a viable social and political alternative.

Lastly, the presidential address of 1990 MESA was given by the outgoing president, Yvonne Y. Haddad of the University of Massachusetts in Amherst, who emphasized the need for quality research in Middle East studies. Haddad emphasized the notion that genuine Middle East scholars should participate in the decision-making process of this country, especially in relation to the Middle East, which is presently the tensest area in the world. She also discussed the need to fund research in different fields, particularly women's studies and Islamic studies.

Ibrahim M. Abu-Rabi

Rockefeller Fellow

Middle Eastern Center

University of Texas at Austin Austin, Texas 